University of Rhode Island

DigitalCommons@URI

\title{
Mobilizing Doubt: The Legal Mobilization of Climate Denialist Groups
}

Aaron J. Ley

University of Rhode Island, ajley@uri.edu

Follow this and additional works at: https://digitalcommons.uri.edu/psc_facpubs

The University of Rhode Island Faculty have made this article openly available.

Please let us know how Open Access to this research benefits you.

This is a pre-publication author manuscript of the final, published article.

Terms of Use

This article is made available under the terms and conditions applicable towards Open Access

Policy Articles, as set forth in our Terms of Use.

Citation/Publisher Attribution

Ley, A. J. (2018), Mobilizing Doubt: The Legal Mobilization of Climate Denialist Groups. Law \& Policy, 40:

221-242. doi:10.1111/lapo.12103 Available at: https://doi.org/10.1111/lapo.12103

This Article is brought to you for free and open access by the Political Science at DigitalCommons@URI. It has been accepted for inclusion in Political Science Faculty Publications by an authorized administrator of DigitalCommons@URI.For more information, please contact digitalcommons-group@uri.edu. 


\title{
Mobilizing Doubt: The Legal Mobilization of Climate Denialist Groups Aaron J. Ley
}

\begin{abstract}
The climate change counter-movement (CCCM) deploys a broad repertoire of tactics in its effort to cast doubt on the science of climate change. One important yet understudied tactic is the effort by CCCM groups to use open records laws in scientifically uncertain areas to cast doubt on the accuracy of scientific information. This article explores the use of this tactic by CCCM groups and adds to the legal mobilization literature in three ways. First, it traces the origin of CCCM groups to the broader conservative legal movement of the 1970s that challenged the dominance of the liberal legal network. Second, it shows how CCCM groups waged an open records campaign against climate scientists in Virginia and Arizona, which caused a countermobilization by scientists with their own legal campaigns. Finally, this article provides the first empirical evidence of the effect of CCCM FOIA suits on the activities of university researchers. I find, through in-depth personal interviews with twelve university researchers, that the experience of researchers who have been exposed to open records campaigns has been overwhelmingly negative, has caused them to communicate through different media, and has imposed a new work burden that draws them away from other work responsibilities. I argue that the costs of these tactics are narrowly borne by a concentrated group of scientists whose production of knowledge is a public good that allows us to address the crosscutting and relentless problem of climate change.
\end{abstract}

* The author would like to thank the editor and managing editor, the anonymous reviewers, Brian Krueger, Charles Epp, and Douglas Edlin for the valuable insights that were incorporated into this manuscript. 


\section{Introduction}

As the Earth warms, the politics of climate change keep getting hotter. In 1988, renowned climate modeler James E. Hansen sat before the Senate Committee on Energy and Natural Resources and famously declared that "global warming is now large enough that we can ascribe with a high degree of confidence a cause and effect relationship to the greenhouse effect." (Hansen 1988, 2) Twenty-seven years later in February 2015, Senator James Inhofe (R-OK) brandished a snowball on the US Senate floor as evidence that global warming is overblown. The tactics used by climate deniers ${ }^{1}$ like Sen. Inhofe, which range from attracting media attention to filing lawsuits to acquire the emails of climate scientists, are part of a broader effort that aims to cast doubt on the scientific evidence that supports global warming.

An extensive climate change countermovement (CCCM) has emerged to challenge the insights generated by scientists who seek to understand more about the causes and consequences of global warming. Today's scientists, together with environmentalists who raise public consciousness about the negative effects of climate change, represent forces of reflexive modernization (reflexivity) seeking to address the multijurisdictional, crosscutting, and relentless problem of climate change (see Beck 1992). It has been argued that our mastery of science and its application to industrial capitalism has caused new fields of science to emerge, called "impact science," that seek to address the severe environmental consequences that are borne by current generations and that threaten to be passed on to future ones (McCright and Dunlap 2010). Fields of inquiry that qualify as impact science, like climate science, are increasingly being challenged by advocacy 
organizations and conservative think tanks that, despite their lack of scientific credentials, question the legitimacy of climate science as a field and impugn individual scientists conducting climate research (Brulle and Dunlap 2015; Dunlap and Jacques 2013). This strategy has yielded a large stockpile of contrarian information and strategies-veritable field manuals—that are written by conservative think tank-sponsored authors and published by conservative presses (Dunlap and Jacques 2013; Jacques, Dunlap, and Freeman 2008). A large-scale and sophisticated network of conservative commentators disseminate this contrarian information through the news media by "employ[ing] arguments against global warming that have long been debunked in the scientific literature" and by "repeat[ing] allegations against climate scientists that have no basis," often with "virtual impunity" (Elsasser and Dunlap 2012, 14). Recent empirical studies demonstrate that these efforts are heavily influenced by corporate benefactors and that they powerfully influence the media narrative about climate change (Farrell 2016a, 2016b). Moreover, it has been shown that donor-directed organizations, otherwise known as dark money organizations, serve as the primary funding mechanism that allows CCCM activities to persist (Brulle 2014). For McCright and Dunlap (2010), all of these activities undertaken by CCCM organizations represent a "highly potent force of anti-reflexivity" that seeks to reassert the dominance of the industrial capitalist social order by intimidating scientists and manipulating research in ways that manufacture doubt.

If the production and dissemination of contrarian information to cast doubt on climate science research has captured the imagination and attention of scholars 
as a time-honored tactic of CCCM organizations, then another CCCM strategy that deserves equal attention as part of their broader repertoire of tactics is the execution of open records campaigns to gain access to the data and correspondence of scientists engaged in climate science research. Scholars have long recognized the critical importance of legal resources that, once invoked, raise consciousness and constitute meaning during the hard-fought policy conflicts waged by everyday people making rights-based claims (McCann 1994). Indeed, many of these legal resources were forged in earlier battles being fought by liberal public interest groups as they challenged the power of corporate influence and sought to open administrative policy venues for greater political participation (McCann 1986). While much scholarly attention has focused on the legal mobilization strategies and tactics of grassroots and social movement organizations that are making rightsbased claims, this manuscript examines the adoption of similar tactics by conservative legal groups as they countermobilize against the scientific consensus of climate change. In doing so, this paper shows how CCCM organizations with corporate ties have reappropriated open records laws and now use them in scientifically uncertain and technically complex policy areas to cast doubt on the accuracy of information that is communicated to the lay public. These groups are, in effect, engaging in the consciousness-lowering tactic of manufacturing uncertainty (Michaels 2006), and theories of legal mobilization should begin to take these countermobilization efforts into account. I argue that the costs of these tactics, especially when they are used instrumentally to interfere or cast doubt on the generation of scientific knowledge, are narrowly borne by a concentrated group of 
scientists whose production of knowledge is a public good that allows us to address the crosscutting and relentless problem of climate change.

Given that procedural rights of access were developed by predominately liberal public interest groups to mobilize against corporate power, I am interested in learning about the effects of the adoption of these tactics. In this study I trace the existence of CCCM legal groups to the broader conservative legal movement that emerged to challenge the dominance of the liberal legal network (see Teles 2008). I also describe how the formation of CCCM legal groups was followed by the execution of two high profile litigation campaigns against Pennsylvania State University climate scientist Michael Mann and University of Arizona researchers Jonathan Overpeck and Malcolm Hughes. In response to the CCCM legal campaigns against Professors Mann, Overpeck, and Hughes, I show how the American Association of University Professors (AAUP), the Union of Concerned Scientists (UCS), the Climate Science Legal Defense Fund (CSLDF), and various other actors countermobilized in support of climate researchers. Finally, if CCCM legal groups are now commonly using legal mobilization campaigns as a strategy to undermine reflexivity, then I am interested in the empirical effect of these FOIA campaigns on the behavior and experiences of university researchers. In the last section of this manuscript, I use personal interviews with climate researchers and other university scholars to explore how (and through what means) scholars are communicating about their research in the aftermath of these requests. I turn now to the development and ascendance of climate denialist legal actors and their links to the 
broader conservative legal movement, followed by a discussion of the legal campaigns against Professors Mann, Hughes, and Overpeck.

\section{The Rise of the Conservative Legal Movement and the CCCM Legal Campaign against Professors Mann, Overpeck, and Hughes.}

\section{A. The Conservative Legal Movement and CCCM Organizations.}

Scholars have written extensively about the factors giving rise to the largescale rights-based litigation campaigns undertaken by advocacy organizations that fought for gender equality and civil rights. These movements witnessed the emergence of an institutional support structure of litigants that altered the "supply" of cases at all levels of the judiciary (Epp 1998). Without a similar conservative legal strategy in place, liberals exploited the judiciary as an underdefended policy terrain on which to advance their rights-based claims (Teles 2008). While organizations such as the NAACP and ACLU had for years executed a rights-based legal strategy, Southworth (2005) observes that public interest law firms had emerged and distinguished themselves "by pursuing broader issue agendas and expanding the range of strategies to include not only constitutional litigation but also other types of law reform litigation and administrative and legislative advocacy" (1234-1235). These efforts included passing broad freedom of information and open meetings laws to make bureaucracies more transparent and, it was hoped, accountable to the people.

It was during this time that law schools were built into bona fide producers of public goods for a vast network of liberals that sought policy change through the 
judiciary (Teles 2008). Law schools groomed the next army of public interest lawyers by training them through in-house legal clinics, which allowed young attorneys to hone their skills before entering the real world of legal conflict against experienced corporate attorneys (Teles 2008). Young, energetic, and committed public interest lawyers repeatedly pressured the judiciary to force compliance with environmental, consumer protection, and workplace protection statutes, and federal judges began striking down laws they deemed "arbitrary," "capricious," or an "abuse of agency discretion" (Shapiro 1988).

Conservatives, meanwhile, learned that a strategy for competing with liberals meant replicating the public interest law model by increasing their presence in law schools (Southworth 2005). Wealthy businessmen and chemical manufacturers like John M. Olin were constantly embroiled in conflict with administrative agencies that were now pressured by newly graduated public interest lawyers to zealously regulate. Olin directed his foundation to begin funding programs to bolster the presence of conservatives in higher education and, especially, in law schools, where his foundation supported the establishment of "beachheads" for conservative intellectuals. Another part of the Olin Foundation strategy was to deliver support for conservative intellectuals by funding the establishment of programs in Law and Economics - a legal philosophy that directly challenged the liberal legal paradigmat some of the nation's most elite law schools (Mayer 2016). Another important national development occurred when numerous small chapters of the Federalist Society were formed, allowing conservative ideas to begin gaining more traction in American law schools. The institutionalization of the Federalist Society gave young 
conservatives more opportunities to articulate their ideas through debate, brought what at the time seemed to be off-the-wall legal ideas into the mainstream, and allowed young conservatives to network with one another (Hollis-Brusky 2015; Teles 2008).

Arguably the Olin Foundation's most important strategy was establishing beachheads for conservative legal intellectuals where institutional resources could be used to train a new generation of legal activists on how to mobilize law in support of the industrial capitalist order. One of the most widely recognized sanctuaries for legal conservatives is the George Mason University School of Law (GMUSL), now named the Antonin Scalia Law School. GMUSL was made prominent by Henry Manne whose advocacy for the establishment of Law and Economics training programs for students and practitioners was felt at law schools throughout the country (Teles 2008). Many viewed Law and Economics, built on the neoclassical economic model, as a theoretically elegant vehicle for institutionalizing and justifying free market capitalism in ways that were attractive to law students and practitioners, like judges, who commonly attended Law and Economics seminars. Stephen Teles (2008) described Henry Manne as, .... [having been] able to build a law school [GMUSL] with a durable libertarian character. The ideological coloration of the school allowed it to actively seek to advance the interests of the larger conservativelibertarian movement, by providing an institutional space in which scholars out of the legal academic mainstream can develop a scholarly reputation and move on to higher-status institutions (219).

Today, GMUSL provides students with clinical opportunities and program centers that owe their existence to conservative donors such as DonorsTrust, a 501(c)3 organization that finances climate denialist groups and "was established ... to 
ensure the intent of donors who are dedicated to the ideals of limited government, personal responsibility, and free enterprise."2 The law school also provides students opportunities to gain clinical experience through conservative public interest law clinics such as the George Mason Environmental Law Clinic, which was later renamed The Free Market Environmental Law Clinic after dissociating from the university. ${ }^{3}$ One of the most prominent associates of the Free Market Environmental Law Clinic was its former Director David Schnare, who became a key part of President Donald Trump's EPA Transition Team and maintained a relationship with the American Tradition Institute (ATI), the organization that brought lawsuits against prominent climate researcher Michael Mann for access to his emails.

\section{B. The American Tradition Institute vs. Michael Mann and the University of Virginia}

Michael Mann is internationally known for his research that culminated in the "Hockey Stick" graph, which demonstrates a precipitous rise in twentieth century temperature caused by human activity (Mann et al. 1998, 1999). Mann, the recipient of numerous honors and awards for his research, began his academic career at the University of Virginia, where he was an Assistant Professor in the Department of Environmental Sciences from 1999 to 2005. In 2010, after Mann had accepted a position with Pennsylvania State University, Republican Virginia Attorney General Ken Cuccinelli, a self-described climate skeptic, filed a civil investigative demand for emails related to Mann's work. A civil investigative demand allows the Attorney General to subpoena materials from state agencies to investigate fraud. After the request was made, UVA signaled that the university 
would comply with it, but then opposition formed from groups such as the American Association of University Professors (AAUP) and the American Civil Liberties Union (ACLU), causing UVA administrators to reconsider the university's position. Later, the UVA Faculty Senate approved a formal message in support of Michael Mann, stating that

[Cuccinelli's] action and the potential threat of legal prosecution of scientific endeavor that has satisfied peer-review standards sends a chilling message to scientists engaged in basic research involving Earth's climate and indeed to any scholars in any discipline. Such actions directly threaten academic freedom and, thus, our ability to generate the knowledge upon which informed public policy relies (Mann 2012, p. 238-239).

That next month, UVA challenged Cuccinelli in state court and won, successfully demonstrating that the Attorney General lacked evidence that Mann was engaged in fraud, but the Attorney General's office nevertheless appealed to the Virginia Supreme Court, where it again lost. ${ }^{4}$ Although Cuccinelli fell short in his case against UVA, the litigation nevertheless reinforced his bona fides as a candidate conservative enough to win the Virginia GOP's 2013 gubernatorial primary race and brought renewed attention to the possibility of exposing salacious emails. This, in turn, prompted ATI to submit a request for Mann's emails, this time under Virginia's FOIA law.

ATI is a 501(c)3 organization that describes itself as a free market think tank. Its General Counsel, David Schnare, a former EPA employee, has served alongside well-known climate denialists like Myron Ebell on the Trump Transition landing team. Schnare's collaborator, Chris Horner, a "Senior Fellow" at the Competitive Enterprise Institute, an organization with ties to the coal industry, is the Senior 
Legal Fellow at ATI, "where he provides strategic and legal counsel on cases

involving Freedom of Information Act (FOIA) filings and government

transparency."

After ATI submitted its public records request, the Union of Concerned

Scientists (UCS), AAUP, and the ACLU asked UVA President Teresa Sullivan to invoke

exemptions under the state FOIA law to protect Mann's emails from being released

(States News Service 2011a). The records that are exempt from the open records

law include

data, records or information of a proprietary nature produced or collected by or for faculty or staff of public institutions of higher education, other than the institutions' financial or administrative records, in the conduct of or as a result of study or research on medical, scientific, technical or scholarly issues, whether sponsored by the institution alone or in conjunction with a governmental body or a private concern, where such data, records or information has not been publicly released, published, copyrighted or patented (Virginia Code $\S 2.2-3705.4(4))$.

Disagreement formed between ATI and UVA over the meaning of "proprietary," with the university arguing that it should be interpreted broadly and ATI arguing otherwise. With both sides at an impasse, the trial court ordered that UVA label as proprietary whichever emails in its possession it deemed so and then to produce them

in a form to be agreed upon between the parties ... [so that ATI would] have 90 days after receipt of the Exempt Information to review it, negotiate with the Respondents, and if they choose, file a petition with the Court for in camera review for determination as to whether the Respondent properly designated the records as Exempt Information (American Tradition Institute, et al. v. Rector and Visitors of the University of Virginia, et al. 2014 at 4). 
At about the same time that the trial court required both sides to settle their disagreement under the FOIA law, Mann received support from the American Association for the Advancement of Science (AAAS), publisher of the journal Science, which denounced the "personal attacks," "harassment," "death threats," and "legal challenges" that Mann was being subjected to (PR Newswire 2011b; Foster 2011).

That fall, Mann received additional support when Scott Mandia of Suffolk County Community College formed what became the Climate Science Legal Defense Fund (CSLDF) (State News Service 2011c; Hurley 2011). Within 24 hours of writing a letter to his colleagues to solicit money in support of Mann's legal defense, Mandia raised $\$ 10,000$ from the scientific community, which grew to $\$ 30,000$ by January 2012. In addition to providing financial support, CSLDF formed relationships with Public Employees for Environmental Responsibility (PEER), which had the organizational capacity to do things that CSLDF could not. PEER organized a network of law firms that pledged legal services to embattled scientists throughout the United States (Jamieson 2012), which allowed Mann to file a motion to intervene in UVA's case, arguing that his former employer could not alone protect his "interests in privacy, academic freedom, and free speech," a motion that was granted that November (American Tradition Institute 2014 at 5).

Almost a year passed, and, the following September, Prince William County Circuit Court Judge Paul Sheridan ruled in favor of Mann and UVA (Jackman 2012). ATI appealed the circuit court decision to the Virginia Supreme Court, where the state's highest court was tasked with determining what was meant by "proprietary." Mann's legal team argued that if the definition of "proprietary" proffered by ATI was 
adopted by the court, then it followed that Virginia's General Assembly must have intended a narrow definition of "proprietary" while fully aware that a narrow definition of the term would cause the commonwealth's public universities to suffer competitively against private universities. To advance its argument, UVA's Vice President and Provost John Simon, who at one time served as a Vice-Provost at Duke University, submitted an affidavit that the Court relied upon in making its ruling. Simon wrote,

Scientists at private institutions such as Duke, where I previously worked, that are not subject to state freedom of information statutes, will not feel that it is possible to continue collaborations with scientists at public institutions if doing so means that every email or other written communication discussing data, preliminary results, drafts of papers, review of grant proposals, or other research related activities is subject to public release under a state FOIA in contravention of scholarly norms and expectations of privacy and confidentiality.... I can state unequivocally that recruitment of faculty to an institution like the University of Virginia will be deeply harmed if such faculty must fear that their unpublished communications with their scientific collaborators and scholarly colleagues are subject to involuntary disclosure (American Tradition Institute 2014 at 15-16).

The Virginia Supreme Court agreed, ruling that Mann's emails fell under the ordinary meaning of the term "proprietary" and that the legislature never could have intended to place the commonwealth's public institutions at a competitive disadvantage against private ones. The Court specifically found that competitive disadvantage implicates ... harm to university-wide research efforts, damage to faculty recruitment and retention, undermining of faculty expectations of privacy and confidentiality, and impairment of free thought and expression (American Tradition Institute 2014 at 15 ). 
This high-profile legal victory in Virginia gave American scientists the national recognition needed to draw more attention to their efforts to protect the integrity of the research process.

After the Virginia case, climate researchers continued building the additional capacity needed to win future legal battles against climate change deniers, who were increasingly turning to the courts. In 2015, for instance, the UCS's Michael Halpern produced a 20-page report through its Center for Science and Democracy called "Freedom to Bully: How Laws Intended to Free Information are used to Harass Researchers," which detailed examples of egregious "open records attacks" and how '[s]nooping on researchers' email has become the twenty-first century equivalent of tapping their phone lines or bugging a lab's water cooler" (3). Most importantly, the litigation campaign against climate researchers produced the CSLDF, which now uses Columbia Law School as its mailing address and has grown to a staff of four.

\section{E\&E Legal vs. Jonathan Overpeck and Malcolm Hughes}

Michael Mann's success in Virginia did not stop ATI from using open records statutes to request emails from others who were associated with Mann and the professional community of climate scientists. ATI changed its name to the Energy \& Environmental Legal Institute (E\&E Legal) and then set its sights on Jonathan Overpeck and Malcolm Hughes, two prominent climate scientists from the University of Arizona, who E\&E Legal claimed "were prominently featured in two separate [email] releases in 2009 and 2011 known colloquially as 'Climategate'” 
(Energy \& Environmental Legal Institute 2014 at 4). In Arizona, public records are made available to "inspection by any person and at all times" (A.R.S. § 39-121). Under this law, E\&E Legal submitted an open records request to the University of Arizona for a period from 1999 to 2006,6 producing 1,600 pages of documents that were submitted to the organization and over 1,700 that, "due to considerations of privacy, confidentiality, academic freedom, and the competition for and retention of faculty members, and other factors," were withheld (Energy \& Environmental Legal Institute v Arizona Board of Regents, et al. 2015b at 4). E\&E Legal promptly sued the Arizona Board of Regents (AzBOR) for the 1,700 emails, arguing that disputes raised under the Arizona public records statute should always be resolved with the presumption being in favor of disclosing public records, unless the state can demonstrate that the delivery of the records will cause material harm. E\&E Legal, furthermore, argued that "generalized" claims of academic freedom are "insufficient as a matter of law" (Energy \& Environmental Legal Institute 2014 at 13). Its attorneys argued,

that the chilling effect cited by AzBOR is contrary to fundamental scientific principles of openness and transparency which promote public confidence in scientific research...[and that the benefits of] the content of the contested emails to the public at large greatly exceeds any potential reduction in collaboration between some scientists and professors at public universities (Energy \& Environmental Legal Institute $v$ Arizona Board of Regents, et al. 2015a).

E\&E Legal, furthermore, argued that AzBOR had abused its discretion and acted in an arbitrary or capricious matter by not disclosing the emails (Energy \& Environmental Legal Institute 2015a). 
Hughes and Overpeck, however, responded that the open records requests

were intrusive and time intensive. In an affidavit filed with the court, Professor Hughes (2014), who was Mann's co-author, explained that complying with the open records request,

was and continues to be a very burdensome and dispiriting task that diverted my energies and attention from productive work to a notable degree. The task of reviewing my emails for information responsive to Petitioner's broad demands took at least ten weeks of my time.... This E\&E matter deprived me of one of the small handful of summers remaining in my career. Given my general level of activity, this is a significant loss, not only to me professionally, but also to my department at the UA (4-5).

Furthermore, Hughes described in his affidavit how public records requests had impacted his collaboration with others. He testified that,

I have been directly informed by several colleagues that they have limited their email communications with me because I have been targeted in public records requests. As email is the essential medium of scientific cooperation in the modern world, there is no doubt that this chilling effect has been an obstacle to collaboration (Hughes 2014, 8-9).

In addition to his claim that the open records requests had interfered with his ability to collaborate with others, Hughes also testified that these requests undermined principles of academic freedom at public universities. His affidavit included a reference to a letter he sent to UVA's president Teresa Sullivan in support of Mann, in which he wrote,

Nothing is more likely to squash the creativity of America's scientists than the ever-present ear of a hostile listener intent on finding, at all costs, the appearance of malfeasance. Nothing is more calculated to discourage research into topics that may challenge powerful interests than the telephone tap, or its modern cousin the carefully cherrypicked phrase in one out of thousands of emails.... It is indeed the modern 'hostile ear' (Hughes 2014, 9). 
In support of this testimony, the University of Arizona, in arguing against disclosure of the records, claimed that "the basis for not producing these documents is that to do so would have a chilling effect on the ability and likelihood of professors and scientists engaging in frank exchanges of ideas and information" (Energy \& Environmental Legal Institute 2015a at 3).

In addition to hearing these arguments, Pima County Superior Court Judge James Marner examined a collection of ninety representative emails, which ranged from one page to over 800 pages in length, and described them as so "technical and esoteric" that he was not "able to fully comprehend the substance of [them]" (Energy \& Environmental Legal Institute 2015a at 1). He ruled that AzBOR had not abused its discretion to withhold the emails, a decision that E\&E Legal appealed to the Arizona Court of Appeals that same year. This time, the appellate court ruled that the standard of review of placing the burden on E\&E Legal to persuade the court of disclosure was wrongly chosen. Rather, the appellate court ruled, the trial judge should have weighed whether the "disclosure of the records would be detrimental to the best interests of the state against the presumption in favor of disclosure" (Energy \& Environmental Institute 2015b at 8). In response to this ruling, the case was remanded back to the Pima County Superior Court where, on June 14, 2016, Judge Marner ruled under the alternative standard of review that Overpeck and Hughes were compelled to produce their email correspondence and deliver it to E\&E Legal. Judge Marner wrote,

...the Court finds that AzBOR has not met its burden justifying its decision to withhold the subject emails. In making this finding, the Court does not ignore the repeated "chilling effect" concerns raised in the affidavits and in the pleadings. However, the Court concludes that 
this potential harm is speculative at best, and does not overcome the presumption favoring disclosure of public records containing information about a topic as important and far-reaching as global warming and its potential causes.... [AzBOR goes] beyond championing academic freedom and, in effect, promotes the creation of an academic privilege exception to [the Arizona open records law]. This is a proposition more properly made to the legislature rather than the courts (Energy \& Environmental Legal Institute $v$ Arizona Board of Regents, et al. 2016 at 4).

The not-yet-resolved Arizona litigation raises a key, yet unanswered, empirical question about the effect of disclosure on the research activities of public employees at universities: to what extent do these open records campaigns affect the research activities, including those relating to speech, of public university researchers?

While the open records campaigns in Virginia and Arizona represent two high-profile efforts by ATI to release scholarly correspondence, a PBS Frontline documentary called Climate of Doubt demonstrates how numerous climate researchers across the country are now being targeted by these campaigns. That is why it is critically important to learn more about the empirical effect of FOIA requests on the day-to-day activities of university professors and researchers. If there is support for the legal claims of climate researchers and public universities that open records requests of research and email correspondence (1) can place public universities at a disadvantage vis-à-vis private institutions, (2) will have a chilling effect on university professors in their deliberations with colleagues, and/or (3) will take away time that would ordinarily be spent conducting research for the public, then I should expect to see evidence of those claims during in-depth personal interviews with public university researchers and professors who have experienced these requests. In order to collect empirical evidence concerning the effect of these 
FOIA requests, I conducted personal interviews with twelve university researchers and professors who have been asked to comply with open records requests for scholarly correspondence.

\section{Methodology}

To understand the extent to which open records request campaigns affect the behavior of public university professors, I conducted semi-structured interviews with researchers and scientists to learn more about the experiences of those having to comply with them. It became immediately evident that I would only be able to determine the impact of these open records requests by increasing my sample size to include, in addition to climate scientists, other researchers and scientists who have been asked to comply with these requests. I therefore widened my sampling strategy to include all researchers who have experienced requests for scholarly correspondence on some matter of public policy. ${ }^{7}$ Doing so allowed me to increase the number of observations, making it possible to "transform an intractable problem that has an indeterminate research design into a tractable one" (King, Keohane, and Verba 1994, 208). While it is reasonable to assume that university researchers outside of the climate research network will report similar experiences as climate researchers in my interviews, I am nevertheless careful to describe when a participant is one of the three climate researchers that are part of my sample when reporting my interview data.

Qualitative research designs that examine a limited number of in-depth observations typically employ a purposive sampling method (e.g., Fenno 1978). Given the challenges of increasing the sample size of my pool of interviewees, I 
employed a diverse sampling strategy that required (1) identifying researchers who were publicly identified as having been required to comply with an open records request and (2) recruiting participants through listservs of both the Law \& Courts Section of the American Political Science Association and the National Oceanic and Atmospheric Administration (NOAA). After each interview, I employed a snowball sampling strategy where participants were asked to identify additional recipients of open records requests. This type of sampling strategy is often used when "studying a relatively select, rare, or difficult-to-locate population" (Johnson, Reynolds, and Mycoff 2016, 229). In all, I completed twelve in-depth phone interviews with respondents who reported having been asked to comply with an open records request, including three climate researchers and nine others specializing in the fields of labor studies, biotechnology, political science, and public health.

I used a semi-structured interview approach while asking respondents questions during my interviews. Semi-structured interviews typically involve a structured set of questions, but also allow investigators to ask follow-up questions and to clarify points that are made by respondents (Obasogie 2014). The confidential interviews, which last no less than thirty minutes and no longer than one hour, involved questions relating to the time spent complying with FOIA requests, the effect of FOIA requests on relationships with colleagues both inside and outside of the university, and the effect of the requests on activities relating to how the respondents express research findings and viewpoints both within and outside of academic settings. In light of the fact that my interview respondents were professionals who had experienced an intrusion of privacy, I recognized the 
importance of masking the identities of interviewees as soon as I began transcribing the audio-recorded interviews (Kvale 1996). In some cases, these individuals had already had the experience of being thrust into the public spotlight through no choice of their own. In order to reassure my respondents that their audio recorded interviews would not be discoverable by an open records request through my university, I immediately transcribed the interviews verbatim and deleted the audio recording. ${ }^{8}$ Due to the semi-structured nature of the interviews, the coding scheme employed for this study was straightforward: initial reactions upon learning about the open records requests were coded as positive, negative, and neutral; the time burden of complying with the request was coded as minimal, moderate, or disruptive; respondents' reported changes in communication patterns in response to the requests were coded as changing to non-official email accounts, changing to more phone calls to avoid email use, changing to become more cognizant of what is written in emails, and no effect; whether respondents reported experiencing an academic chilling effect was coded as either having a chilling effect or having no chilling effect; and the effect of the information request on collaboration with peers outside of the university was coded as either having an effect or having no effect.

Before sharing the empirical results of these interviews with FOIA request recipients, it is important to note at the outset that one shortcoming of my sampling strategy is that I may only be speaking with researchers who are willing to share their experiences with me. For instance, I suspect that I may have undersampled researchers whose negative experiences may have kept them from speaking with me. One person who chose not to participate, for example, was concerned that 
participating in the interview would cause the organization that had originally filed an open records request against her to retaliate. If my sample of participants includes only researchers who are willing to speak about their experiences, then it is reasonable to conclude that the personal interviews that I have collected so far might represent a "best-case-scenario" as it relates to the effect of FOIA requests. Furthermore, the respondents that have been interviewed are sharing perceptions with me, and so the interview responses may not accurately reflect the underlying effects of having experienced a FOIA request. In other words, the insights that are drawn from my interview should be interpreted with caution because they might understate the empirical effect of open records requests on the activities of university researchers. With this caveat having been made clear, I turn now to the interview results.

\section{Evidence of FOIA Request Effects from Interviews with University Professors.}

\section{A. Initial Reactions after Learning about Information Requests.}

While working to understand the effect of FOIA requests on university professors, I was interested in learning more about the range of emotions that researchers experience after learning about a FOIA request for the first time. If the initial reaction to learning about a FOIA request was negative or positive, then I expected that experience to be reflected in the participant's response to a question about his or her initial reaction. One participant described anxiety after initially learning about the request, responding,

My first impression was that [a group that disagreed with my research] was issuing the FOIA request and they had been publicly not 
nice to me [in the past]. They've attacked me in public with press releases and website stuff, and I decided to take the high road. But my first impression was that they were escalating something, and I was uncomfortable with the FOIA request because of that at first (Personal Interview \#1).

One climate researcher described experiencing panic after learning about the request but then experiencing a completely different range of emotions. This researcher responded,

I think you panic. You're also mad because it was pretty clear that what these people were doing was using a really good law.... They weren't trying to understand anything in particular. They were fishing through my emails hoping to find something that was embarrassing . . . so I was a little bit mad (Personal Interview \#5).

Another pre-tenure female scientist, who had not yet learned that an open records request had been made, received a phone call from her dean who wanted to arrange a meeting. She explained her initial reaction after having learned about the request by recounting the following story:

I was scared. I was mostly scared because when the dean wants to talk to you and you don't know why and they won't put it in writing, that's kind of a big deal.... To be honest, even though I have never done anything wrong, I was scared and angry (Personal Interview \#10).

Yet another climate researcher expressed shock at being asked to comply with a FOIA request:

Why is this happening? I'm a scientist, I'm trying to understand how the Earth works, I'm not trying to do anything that's political.... I understand that this has become a political football, but that doesn't mean I'm doing anything related to that, so it was shocking because I never thought that I would be FOIA'd for that kind of information (Personal Interview \#6).

While shock and panic might best describe the initial reactions from university researchers, others reported being confused about what to do after receiving a FOIA 
request. One climate researcher was especially confused because, after receiving a FOIA request for the first time, the researcher was working as part of a network of state and federal institutions. The researcher explained,

It was unclear if I had to comply [with the request]. What really was horrible was that I contacted [my organization's] attorney and their general counsel. They didn't know what to do. I contacted the university counsel. They didn't know what to do. Then I contacted [another organization's] general counsel. They made the request, so they kept telling me, "Oh just hand them over and we will decide what's discoverable." It got bad enough that I almost thought about getting my own attorney because of this (Personal Interview \#3).

While a number of researchers were initially confused when first notified that their records were requested, others described the requests as a nuisance. Public employees who interpreted the requests as a nuisance also explained that the organization requesting their records was doing so as part of a "fishing expedition" or a "witchhunt." One participant explained, ... it was a pain in the ass having to deal with this when there were real things I was working on. When I say that this is harassment, one of the things is that they want to have you occupied with responding to them rather than doing the substantive work that you are doing. When I say that it is a fishing expedition, its because it was-the [search] terms [requested] had no obvious relationship to each other and included lots of terms that had nothing at all to do with my work, so it was obviously clear to me that this was not an inquiry into a specific thing but was a "let's see what we can find and let's harass him to do all this searching for us." So that was my initial reaction: this is a pain in the ass (Personal Interview \#7).

The insights that were drawn from my interviews with women in the profession also shed light on the differential impact of these requests on their workplace experiences. I had the opportunity to interview three women in the profession who experienced these requests, and two out of the three women used 
the analogy of having a stranger rummaging through their underwear drawers to describe their experiences. One described it this way:

Ridiculous how many emails we had to go through. Hundreds of thousands of emails, which-just knowing anyone is going through your email line by line is very uncomfortable. It's like someone rustling through your underwear drawer. You know it's all clean, but you don't want anybody doing it, right? (Personal Interview \#12).

Another researcher described the experience as "like someone is digging through my underwear drawer, but all I have in my underwear drawer is underwear, and in the end everyone wears underwear" (Personal Interview \#10). All three of the women in the profession that I interviewed reported having experienced violations of privacy as part of their efforts to comply with these information requests. Yet, not all of the reactions to learning about FOIA requests were negative. One participant had experienced FOIA requests multiple times due to having a history of employment in government. This employee took the information request in stride, and explained how the request actually "set the record straight":

In some ways I was thankful for the opportunity to set the record straight to show [the requestor], \#1 that [the requestor] had written several blog posts about how I ... was only teaching one course in the fall semester and I was able to document that that was not the case.... It really gave me a chance to document a bunch of stuff [my requestor] would have never seen just by looking at the [university] website. I kind of thought it was, in the end, sort of a good thing because it kind of shut [my requestor] up (Personal Interview \#2).

Overall, eleven out of twelve of my participants reported experiences that can be described as negative-words like "shock," "panic," "scared," "nuisance," "harassment," "disturbed," "upset," "worried," and "confusion" were all used- after initially learning about these information requests, while only one of my 
participants expressed a positive experience of being able to "set the record straight."

\section{B. The Time Burden of FOIA Requests}

When litigants challenge open records requests through the courts, they usually claim that FOIA requests take away time that they would ordinarily be able to spend with students, in research, or on service-related activities. In the affidavit signed by Malcolm Hughes (2014), he claimed to have spent an inordinate amount of time attempting to comply with E\&E Legal's open records request. It is clear that researchers, such as Professor Hughes, who legally challenge these requests will spend more time on them than those who do not, and so it is important to note that all but one of my participants did not formally challenge these requests in court. Furthermore, some universities assign an employee to serve as the custodian of public records so that if there is an information request, it is an administrator, attorney, or staff member who fulfills the request.

My research participants reported a range of responses when asked about the time they spent complying with FOIA requests, and their answers depended on the extent to which administrators were responsible for compliance and the number of exceptions that were articulated in the state open records law. One respondent described the time spent complying with the request as a "minor nuisance" (Personal Interview \#2). When asked if it took away from time spent with students, research, or service the respondent replied,

Really none at all... I probably spent an hour on the phone with the lawyer. Maybe two phone conversations-a total of an hour. And then probably another hour collecting the records that [the administrator] 
needed from me. So it was just a miniscule part of over a two-week period (Personal Interview \#2).

Another respondent reported that it had a "minor effect," requiring only "two to three hours" to comply (Personal Interview \#1). When administrators were responsible for collecting the emails and addressing the legal issues associated with the request, some of the researchers I spoke with reported that the requests had a very minor effect on the time they spent on their work-related responsibilities. One climate scientist responded,

It had essentially no impact on [teaching, research, or service].... I've heard stories about people having to spend like a summer going through emails. I didn't do any of that. The IT people downloaded the email, they searched all the keywords, and they gave them to the general counsel's office. I probably had to spend maybe a total of a day or two days sort of dealing with legal issues (Personal Interview \#5).

Others, however, reported spending far more time complying with the request, and this might be due to the sophistication of the groups making the requests. One climate scientist reported,

It took me three days culling through my own personal laptop just to make sure, did I have anything? That was really frustrating because it felt like such a waste of time..... It was a witch-hunt, and it just was ridiculous (Personal Interview \#3).

Another climate researcher reported that searching through emails to submit to the university in fulfillment of a FOIA request

took two or three days of my time basically-many thousands of emails-because being on the IPCC assessment, particularly, I had been doing numerous emails everyday. It was later determined by the way that none of those emails connected with IPCC were even allowable because it was a report in progress ... But nonetheless I had to spend a lot of time going through all those. I don't know how much time it ate up but it was certainly a week to ten days. So what happened [was] the university went back to ... the lawyer and said you have to narrow the request because you can't be making such a 
broad thing over such a long period of time. We're talking about thousands of emails here, so the lawyer then came back with a smaller request. So I had to go through them again and extract out what was for that time period. We ended up doing that three different times, until we finally got things. All in all, I don't know how much time it cost me. Probably several weeks of my time. Plus some heartburn having to deal with this [laughs] (Personal Interview \#6).

There were others not involved in climate research who described the email requests as disruptive to their research efforts. One participant explained,

I had probably fifteen hours worth of meetings with my department chair, with the university lawyer, with the faculty union representative. There are only so many hours in a week. I already, to be honest, work about eighty-five to ninety hours a week. Those fifteen hours had to come from somewhere, so it was less time doing research because usually when students are standing at the door you don't ignore them (Personal Interview \#10).

Another researcher estimated that it took eighty hours to comply with one FOIA request, while the smaller requests tended to take between six to ten hours. Overall, of the twelve participants who were interviewed, four participants (Interviewees $\# 1$, \#2, \#7, and \#8) reported that requests had, at most, a moderate effect on the time they spent on teaching, research, and services activities; one participant (Interviewee \#5) described it as having an effect because they spent a couple of days addressing the legal issues; and seven participants (Interviewees \#3, \#4, \#6, \#9, $\# 10, \# 11$, and \#12) described the requests as very disruptive.

\section{Altering Methods of Communication}

As part of my research about the effect of FOIA requests, I am also interested in how these requests change the behavior of employees working for the public. If FOIA requests alter the communication patterns of university researchers, then I expect to see that reflected in the responses of my research participants. The fact 
that public universities provide email systems, in some cases, means that information that becomes part of university servers is in the public domain. Yet if scholars alter their means of communication in response to an information request, perhaps by switching to a private email system, then it is possible that these altered behaviors will eliminate legitimate public information, which would further prevent information of public interest from ever reaching the public domain.

In my interviews, I learned that my research participants reported seeking new ways of communicating with others. One research participant began using the "direct message" function on Twitter to communicate the results of research that had policy implications (Personal Interview \#1). Another "set up a separate Gmail account for correspondence with people that could possibly be political in nature. So I have two email accounts. One with my [university] account, and the other one is a Gmail [account]" (Personal Interview \#4). One climate researcher began avoiding email correspondence altogether after experiencing a FOIA request. According to this participant, "I make a lot more phone calls than I used to, that's the truth. Honestly, in emails there are just certain things ... [to avoid] when we know that there is something that is gonna be a touchy issue" (Personal Interview \#3). Conducting business over the phone became a common theme among researchers in the profession. One put it this way: "We preferred to do direct phone or some other source that couldn't be FOIA'd just to avoid the hassle" (Personal Interview \#12).

While the four participants above actually changed the medium used for communication, others began self-censoring their correspondence with others when using email. One participant became "more conscious of the need for being 
scrupulous about not communicating in a non-official [university] way on my official [university] account" (Personal Interview \#2). A climate researcher reported avoiding telling jokes via email:

[The request] does make me more careful about what I write in emails. My working assumption now is anything I write could be released, so I don't make jokes in emails like I may have done previously.... I don't do that because someone might think I'm being serious or something like that (Personal Interview \#5).

One participant described imagining "a lawyer from the [requestor's] industry looking over my shoulder" when writing emails (Personal Interview \#11). One climate researcher explained that,

I don't put things in emails that could be misconstrued. [I'm] [c] ertainly more cautious about emails, particularly in joking around, as I often do. Just to make sure there wasn't something that somebody's gonna take out of context (Personal Interview \#6).

The same participant went on to express concern about other researchers who might be subjected to FOIA requests,

I think I get more concerned about others.... In emails with [other climate researchers] I would be a little careful in sticking to the topic because we knew it was likely to be FOIA'd. But it didn't keep me from discussing the science or anything; it really was just being a little careful to say things that wouldn't be taken out of context.... There's various colleagues I knew [who] had been FOIA'd or were likely to be FOIA'd, including one of my former students ... who I interact with a lot still. I just have to be a little more careful, but it really hasn't affected what science I do at all. I don't allow it to (Personal Interview \#6).

Some researchers became more careful about disseminating data via email than they had in the past, with one researcher describing it this way:

I think if a colleague has asked me to send some data or send a file or whatever I would have very easily done that. Now, since I'm worried that it can just be grabbed and taken out of context by a FOIA request, 
I'm very reluctant to send those sorts of things by email. I've saved data differently than I used to (Personal Interview \#12).

My interviews with participants shed more light on the effect of FOIA requests on their day-to-day communication patterns in the workplace. Three participants reported using nonofficial university means for communicating (Interviewees \#1, \#4, and \#7), four participants described addressing "touchy" matters or business

over the phone to avoid an email record (Interviewees \#3, \#8, \#10, \#11, and \#12), and six reported becoming more cognizant of how they are communicating information using public email systems (Interviewees \#2, \#5, \#6, \#10, \#11, and \#12).

\section{Communicating Research via Email}

In the litigation surrounding open records requests, organizations like the AAUP and the UCS argue that the request for researchers' email correspondence is likely to have a chilling effect on how researchers deliberate about the policy implications of their research. In fact, Malcolm Hughes and several other researchers who have challenged open records requests have testified about having themselves experienced a chilling effect due to these requests.

If open records requests for the personal correspondence of university researchers do, in fact, have a chilling effect on how researchers deliberate via email, then I expect my research participants to describe those changes in their responses. While above I have shown how several respondents reported altering the methods by which they communicate with others, I learned during my interviews that FOIA requests, no matter how intrusive, did not alter the way many of my 
participants communicated their research findings. Five participants (Interviews

$\# 2$, \#3, \#4, \#6, and \#9) unequivocally responded that the open records requests had

no impact on how they communicate their research findings with others via email.

Here is one of the responses from a climate researcher:

I can honestly say [that the request did not change the way I communicate research].... I've always been in the realm of policy relevance, but not policy perspectives.... I won't say, "because of X result, thou shalt do this." I will say, "Here's a tradeoff related to different decisions one might make from a scientific perspective." I've always been like that.... I just don't wanna look like an asshole (Personal Interview \#3).

One participant described being more "careful about saying things that are within the bounds of my empirical findings" (Personal Interview \#1), while one climate scientist explained,

As I said before, it makes me a little more careful when I write email. I carefully consider what I'm gonna say with the assumption that it will be released at some point. If it never is, fine. But if it is, then I didn't say anything stupid. It hasn't at all changed [how I communicate research findings] (Personal Interview \#5).

Nine of my interviews did not report actually having experienced a chilling effect on scholarly inquiry or discourse about research findings. In one case, the request actually emboldened the participant, a climate researcher, who explained,

I have a very low threshold for outrage. When you do climate science its easy to get outraged at the people who are fighting against the science and trying to stop scientists from working. So, if anything, [the request] sort of incentivized me to do even more (Personal Interview \#5).

Even though the majority of my research participants did not find that open records requests led them to suppress their ideas, one of my respondents reported having 
become more cautious about responding to emails from the general public. This

participant explained,

I have been even more cautious than I was before about who I do interviews with; I sometimes assume that emails that come from people that I don't know who they are, are traps to try to trick me into saying something that would be inflammatory. I feel uncomfortable talking (Personal Interview \#10).

Another participant described being less open about expressing research ideas. The participant described it this way:

It changes my openness I guess. The ease with which I would talk about the research that I'm doing. You'd think that you'd want to do that without worrying about it. You talk about research ideas and findings and what you think about this or that. But I just have to be really careful I think in communications (Personal Interview \#11).

All but one of my research participants did not legally challenge the open records requests, and so it may be possible that those choosing to legally challenge open records requests are more likely to experience chilling effects. The one participant who challenged the open records request in court did report the request having a chilling effect both in how research findings were communicated and in the extent to which the participant engaged in "political activity ... outside of work" (Personal Interview \#[Redacted $\left.]^{9}\right)$. Furthermore, it is worth reminding the reader that my collection of interviews have been drawn from participants who are willing to describe their experiences to me. It is possible that those choosing not to participate made that decision on the basis of having experienced a chilling effect.

\section{E. Collaborating with Peers from Private Institutions}


One negative effect of FOIA requests that is regularly cited by supporters of climate scientists is that collaboration between public and private researchers will suffer if emails from private institutions are caught up in information requests against researchers from public institutions. In fact, both the affidavit filed by Hughes (2014) and the testimony received during the Mann litigation in Virginia suggest that public university professors will be less likely to collaborate with their peers at private universities because doing so would require private university researchers to correspond and share data over public technology systems. I expected to see evidence of that when asking my research participants about their ability to collaborate with others in the aftermath of FOIA requests, yet none of my research participants gave examples of collaboration suffering as a consequence of having experienced a FOIA request.

\section{Discussion and Conclusion.}

By mobilizing open records campaigns against university scientists, it can be argued that conservative legal groups have adopted the same tactics as their liberal public interest forbears. Opponents argue that these campaigns burden the speech rights of university professors and interfere with their professional obligation to generate new forms of knowledge. That is why I set out to learn about the consequences of these tactics. I found through my personal interviews that researchers overwhelmingly report negative experiences after having first learned about a FOIA request, in response to which they adopt new forms of communication to avoid material from being made a matter of public record. They also, depending 
on who is responsible for fulfilling these requests, incur significant time burdens that interfere with the production of research and knowledge.

This is critically important because today's complex environmental problems are knowledge intensive and require the generation of information on a scale never before seen. The consequences caused by the execution of these tactics, moreover, are borne by a small group of public university researchers whose generation of knowledge serves a broad public purpose in addressing the difficult environmental problems that confront today's citizens and that will be passed on to future generations. The requests not only interfere with the production of knowledge but also impose the additional burden of placing public universities at a disadvantage vis-à-vis private institutions. If anti-reflexive groups are successful in their continued assault on knowledge generation at public universities, it is possible that resources for impact science will shift to privately-held institutions where access to knowledge is more limited than in public institutions.

This study of the legal mobilization of conservative public interest groups has additional implications for theories of legal mobilization. Legal mobilization theorists have shown how resorting to legal instruments can democratize the policy process by opening venues to political participation that were once closed and can be a powerful symbol for the marginalized as they work to make rights-based claims (McCann 1994). Open records laws were designed to facilitate access and participation in these venues (e.g., Harrington and Carter 2015), but it appears that today they have become a tool used by CCCM groups to manufacture doubt in fields of impact science. If this is a tactic that is commonly being used by CCCM groups, 
then one can expect that these tactics will be adopted in other policy areas where scientists are actively generating knowledge to address today's complex challenges.

Yet the conclusions that can be drawn from my interviews suggest that open records campaigns have not dramatically affected deliberation among researchers, who continue to interpret data and report their findings. Rather, the norms of careful scientific deliberation appear to be so strong that they are withstanding the threat posed by these litigation campaigns. While I did not find evidence of acrossthe-board chilling effects on academic research, the frequency or magnitude of chilling effects is not dispositive of the potentially negative impact of open records laws on the academic research process. Scholarly breakthroughs might, for instance, be stunted by the self-censorship of a reluctant collaborator who opts against making the kind of impulsive, off-the-wall, or controversial interpretation through email that might otherwise have the potential to spark new ideas and fundamentally alter and extend the frontiers of human and scientific knowledge.

Aside from the empirical effect of the open records campaigns being waged by groups like ATI, there remain important normative concerns about how these tactics are funded. Scholars have argued that other large-scale rights mobilization campaigns through the judiciary are consistent with democratic norms due to their association with broad-based interest groups (Epp 1998). If opaque organizations like DonorsTrust are funding groups like ATI to engage in these litigation campaigns, then it is virtually impossible to determine who is responsible for privately funding this strategic litigation that targets public scholarship. If it is true that groups like ATI do not have a broad membership base, then they are not likely 
to possess the democratic supports that are typical of past rights-based legal campaigns.

Finally, because FOIA and litigation campaigns waged by CCCM groups and others who use transparency laws to comb through emails will persist, public universities should consider formulating policies that mitigate the negative impact of these requests. Several of my research participants described spending less time complying with open records requests when a public records custodian was responsible for university compliance, and so public institutions might consider providing institutional support for employees who are asked to comply with such requests. Universities might also educate new faculty members during orientation about state and university policy regarding public access to emails and appropriate email use. Lastly, it is the responsibility of faculty, and those who represent faculty, to understand the extent to which their state FOIA laws protect email correspondence and other types of proprietary information. If those laws are apt to be abused, then university faculty might consider asking their representatives to clarify those laws, as the University of Rhode Island faculty did in 2017 when it passed a law in Rhode Island that protects public university research. ${ }^{10}$

AARON J. LEY is an Assistant Professor of Political Science at the University of Rhode Island. 


\section{NOTES}

${ }^{1}$ Kemp et al. (2010) differentiate between climate deniers and climate skeptics. According to these authors, while skepticism begins with an open mind and involves the weighing of evidence prior to acceptance of a claim, denialism involves "conviction rather than evidence.... Deniers use strategies that invoke conspiracies, quote fake experts, denigrate genuine experts, deploy evidence selectively and create impossible expectations of what research can deliver" (Kemp et al. 2010, 673).

2 DonorsTrust offers financial backing to the GMUSL Law and Economics Center. For a full list of the donors supporting the GMUSL Law and Economics Center, see http://masonlec.org/donors/ (accessed 05/10/2017).

${ }^{3}$ According to The Free Market Environmental Law Clinic website on 09/12/2017, "the Directors of FME Law engaged in a friendly and supportive discussion with the Dean of the George Mason University School of Law and recognized that the clinic could better perform its function by servicing multiple law schools as a stand-alone clinic. The Board thus directed a name change to reflect this broadened purpose.... [The clinic] remains in close cooperation with George Mason University's School of Law and provides both academic courses and clinical opportunities for GMU Law students and is expanding its externship program to other law schools that have a doctrinal focus on law and economics." Website archive can be found here: https://web.archive.org/web/20161229034021/http://fmelawclinic.org/?page id=36 (accessed 05/07/2018).

${ }^{4}$ According to the opinion of the Court, "The University of Virginia, as an agency of the commonwealth, does not constitute a 'person' under the Fraud Against Taxpayers Act and therefore cannot be the proper subject [of a records request]" (Basken 2012).

${ }^{5}$ See http://eelegal.org/fellows-advisors-2/ (accessed 05/10/2017)

${ }^{6}$ The requests included emails between Malcolm Hughes and Michael Mann, emails between Jonathan Overpeck and Phil Jones at the University of East Anglia Climate Research Unit, and communications between Jonathan Overpeck and Caspar Ammann and/or Eugene Wahl. In addition, ATI requested emails by Jonathan Overpeck that included the following terms: Geophysical Research Letters, Stephen McIntyre, Jay Famiglietti, Michael Mann, Alan Robock, James Saiers, "an agu.org email address," and/or "deadline" (Energy \& Environmental Legal Institute 2014 at 6).

7 I chose to limit my interviews to "correspondence as it relates to matters of public policy" because I did not want to include those who have had requests due to intramural university disputes.

Increasing my sample size beyond climate researchers allows me to generalize about the experiences of all researchers, which is critically important if we are to assume that antireflexive modernization campaigns will occur in academic disciplines other than climate science.

${ }^{8}$ Methodologists claim that there is no standard way of transcribing interviews, but that the style chosen should be made explicit (Kvale 1996). Psychological and sociolinguistic analysis requires a detailed and verbatim transcription, while for my purposes I have opted for a verbatim transcription while leaving out the "hmms" and "umms" that are part of ordinary conversation. Given my interest in the perceptions and initial reactions that respondents had toward the information request, I also made note in the transcription of emotional cues and laughter.

${ }^{9}$ Interview number redacted because of the possibility that including it would undermine the confidentiality of the interview.

10 RIGL §38-2-2 (K). 


\section{References}

Basken, Paul. 2012. “Virginia Supreme Court Rejects Attorney General's Demand for Climate Documents," The Chronicle of Higher Education March 2.

Beck, Ulrich. 1992. Risk Society: Towards a New Modernity. London: Sage Publications.

Brulle, Robert. 2014. “Institutionalizing Delay: Foundation Funding and the Creation of U.S. Climate Change Counter-Movement Organizations," Climatic Change 122: 681-694.

Brulle, Robert, and Riley Dunlap. 2015. “Challenging Climate Change: The Denial Countermovement." In Climate Change and Society: Sociological Perspectives, edited by Riley Dunlap and Robert Brulle. Oxford: Oxford Univ. Press.

Dunlap, Riley, and Peter Jacques. 2013. “Climate Change Denial Books and Conservative Think Tanks: Exploring the Connection," American Behavioral Scientist 57: 699-731.

Elsasser, Shaun, and Riley Dunlap. 2012. "Leading Voices in the Denial Choir: Conservative Columnists' Dismissal of Global Warming and Denigration of Climate Science," American Behavioral Scientist 57: 754-776.

Energy \& Environmental Legal Institute. 2014. “Petitioners' Opening Brief.” Pima County Superior Court, Arizona. Case No. C2013-4963.

Epp, Charles. 1998. The Rights Revolution: Lawyers, Activists, and Supreme Courts in Comparative Perspective. Chicago: Univ. of Chicago Press.

Farrell, Justin. 2016a. "Network Structure and Influence of the Climate Change Counter-Movement," Nature Climate Change 6: 370-374. 
--- 2016b. “Corporate Funding and Ideological Polarization about Climate Change," PNAS 113: 92-97.

Fenno, Richard. 1978. Home Style: House Members in their Districts. New York: HarperCollins

Foster, Joanna. 2011. “Group Condemns Harassment of Climate Scientists," The New York Times Blogs June 29.

Halpern, Michael. 2015. “Freedom to Bully: How Laws Intended to Free Information Are Used to Harass Researchers,"Center for Science and Democracy at the Union of Concerned Scientists February.

Hansen, James E. 1988.

Harrington, Christine, and Lief Carter. 2015. Administrative Law \& Politics: Cases and Comments, $5^{\text {th }}$ Edition. Washington, DC: CQ Press.

Hollis-Brusky, Amanda. 2015. Ideas with Consequences: The Federalist Society and the Conservative Counterrevolution. New York: Oxford University Press.

Hughes, Malcolm. 2014. “Declaration of Dr. Malcolm Hughes.” Arizona Pima County Superior Court. Case No. C2013-4963.

Hurley, Lawrence. 2011. “Climate: Legal Fund Formed to Assist Climate Emails Scientist Mann," E\&E News PM September 12.

Jackman, Tom. 2012. “U.Va. Wins Key Ruling in Prince William Global WarmingFOIA Case Involving Michael," Washington Post September 18.

Jacques, Peter, Riley Dunlap, and Mark Freeman. 2008. “The Organisation of Denial: Conservative Think Tanks and Environmental Scepticism," Environmental Politics 17: 349-385. 
Jamieson, Amber. 2012. “A Fighting Fund for Climate Scientists Battling FOI Requests," Crikey January 30.

Johnson, Janet Buttolph, H.T. Reynolds, and Jason Mycoff. 2016. Political Science Research Methods, $8^{\text {th }}$ Edition. Los Angeles, CA: CQ Press.

Kemp, Jeremy, Richard Milne, and Dave Reay. 2010. “Sceptics and Deniers of Climate Change Not to Be Confused," Nature 464: 673.

King, Gary, Robert Keohane, and Sidney Verba. 1994. Designing Social Inquiry: Scientific Inference in Qualitative Research. Princeton, NJ: Princeton Univ. Press.

Kvale, Steinar. 1996. InterViews: An Introduction to Qualitative Research Interviewing. Thousand Oaks, CA: Sage Publications.

Mann, Michael. 2012. The Hockey Stick and the Climate Wars: Dispatches from the Front Lines. New York: Columbia Univ. Press.

Mann, Michael, Raymond Bradley, and Malcolm Hughes. 1998. “Global-Scale Temperature Patterns and Climate Forcing over the Past Six Centuries," Nature 392: 779-787.

-- 1999. “Northern Hemisphere Temperatures during the Past Millennium: Inferences, Uncertainties, and Limitations," Geophysical Research Letters 26: $759-762$.

Mayer, Jane. 2016. Dark Money: The Hidden History of the Billionaires Behind the Rise of the Radical Right. New York: Doubleday.

McCann, Michael. 1986. Taking Reform Seriously: Perspectives on Public Interest Liberalism. Ithaca, NY: Cornell Univ. Press. 
--- 1994. Rights at Work: Pay Equity Reform and the Politics of Legal Mobilization. Chicago: Univ. of Chicago Press.

McCright, Aaron, and Riley Dunlap. 2010. "Anti-Reflexivity: The American Conservative Movement's Success in Undermining Climate Science and Policy," Theory, Culture \& Society 27: 100-133.

Michaels, David. 2006. “Manufactured Uncertainty: Protecting Public Health in the Age of Contested Science and Product Defense," Annals of the New York Academy of Sciences 1076: 149-162.

Obasogie, Osagie. 2014. Blinded by Sight: Seeing Race through the Eyes of the Blind. Stanford, CA: Stanford University Press.

PR Newswire. 2011b. "Statement from American Tradition Institute Environmental Law Center in Response to American Association for the Advancement of Science's Misleading Accusations Against ATI Today," PR Newswire June 29. Shapiro, Martin. 1988. Who Guards the Guardians? Judicial Control of Administration. Athens, GA: Univ. of Georgia Press.

Southworth, Ann. 2005. "Conservative Lawyers and the Contest over the Meaning of 'Public Interest Law.' UCLA Law Review 52: 1223-1278.

State News Service. 2011a. "University of Virginia Will Use Exemptions for Requests for Scientist's Private Documents," States News Service, April 27.

---. 2011b. "Scientist Intervenes in Virginia Email Case to Protect Rights," States News Service, September 6.

Teles, Steven. 2008. The Rise of the Conservative Legal Movement. Princeton, NJ: Princeton Univ. Press. 


\section{Cases Cited}

American Tradition Institute, et al. v Rector and Visitors of the University of Virginia, et al. Virginia Supreme Court. Record No. 130934. (VA 2014).

Energy \& Environmental Legal Institute v Arizona Board of Regents, et al. Arizona Superior Court, Pima County. Case No. C20134963. (AZ 2016).

Energy \& Environmental Legal Institute v Arizona Board of Regents, et al. Arizona Superior Court, Pima County. Case No. C20134963. (AZ 2015a).

Energy \& Environmental Legal Institute v. Arizona Board of Regents, et al. Arizona Court of Appeals, Division Two. No. 2 CA-CV 2015-0086. (AZ 2015b). 